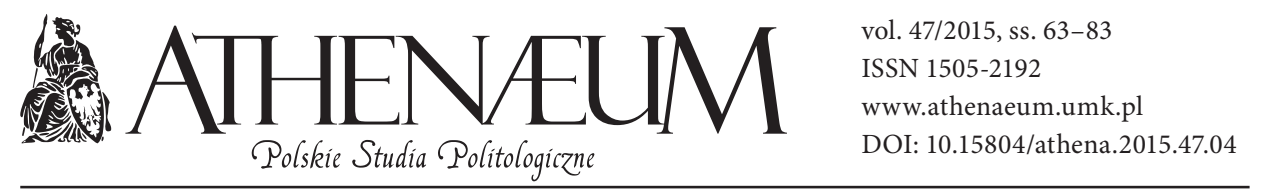

\title{
CZY UCZYMY O TYM, W JAKI SPOSÓB BADAMY?
}

\author{
Pawet Ścigaj*
}

\section{DO WE TEATCH WHAT WE DO IN RESEARCH?}

\begin{abstract}
This paper is based on an assumption that any scientific discipline should be characterized by compatibility between the methods and techniques that are taught and the methods and techniques that are actually used in scientific research. This concerns political science as well. Content analysis of selected syllabi of methodological courses and 280 papers published in 8 polish political science journals shows that there are important differences between teaching about methods and techniques and using them in practice. According to the results, political scientists teach about questionnaires, observations, experiments, surveys, and other methods and techniques specific to social science, but they rarely use them. Only $12,1 \%$ of the articles mentioned what methods and techniques are used and those listed above were very seldom pointed out. Among the articles in which methods and techniques used were not mentioned the most popular method was the one that can be called "critique of written sources" and methods like historical, institutional, and comparative. It seems to be very important that those methods were rarely present in the analyzed syllabi. In sum, it might be said that we do not teach what we do in research. This answer for the title question should be reconsidered as a starting point for possible changes in teaching methodology and also in publishing policy in political science journals.
\end{abstract}

\section{KEYWORDS}

methodology of political science, methods and techniques, methodological courses and teaching

* Uniwersytet Jagielloński w Krakowie, Instytut Nauk Politycznych i Stosunków Międzynarodowych. 


\section{WPROWADZENIE}

Prezentowane w tym artykule zagadnienia są inspirowane badaniami Andrew Bennetta, Aharona Bartha oraz Kennetha R. Rutherforda, którzy poddali analizie 2207 artykułów publikowanych na przestrzeni blisko 30 lat w 10 politologicznych czasopismach naukowych oraz 30 programów kursów metodologicznych oferowanych przez wybrane jednostki kształcące w zakresie nauki o polityce ${ }^{1}$. Badania te przyniosły kilka interesujących informacji, z których trzy wydają się szczególnie ciekawe: po pierwsze, w publikacjach naukowych wcale nie widać znaczącej przewagi metod opartych na modelowaniu formalnym; po drugie, relatywnie małemu zainteresowaniu metodami jakościowymi na poziomie nauczania towarzyszy spore ich wykorzystanie w badaniach; po trzecie, pomimo znacznej liczby studiów z użyciem metod jakościowych ich wykorzystanie w ostatnich latach się zmniejsza².

W związku z powyższymi wnioskami nie dziwi myśl, że podobna analiza polskich periodyków oraz sylabusów kursów metodologicznych mogłaby być również interesująca i wartościowa. Pytanie, czy w Polsce uczymy o tym, w jaki sposób badamy, nasuwa się tu niemal natychmiast. Jest to tym bardziej ciekawe, że przecież problem „politologicznej metody” jest jednym z żywiej dyskutowanych w ostatnich dziesięcioleciach. Więcej jeszcze, poszukiwanie specyficznej dla politologii metody, która przesądzałaby o politologicznym charakterze badań i pozwalała jednoznacznie wskazać granice dyscypliny, jest niezmiernie ważnym elementem trwającej od wielu lat debaty nad tożsamością politologii w Polsce. Dyskusji nierozstrzygniętej, by nie powiedzieć - nierozstrzygalnej. Funkcjonują w niej dwa główne obozy: zwolenników autonomiczności metodologicznej dyscypliny ${ }^{3}$ oraz stronników metodologii pluralistycznej․ I choć wielu współczesnych politologów skłania

${ }^{1}$ Do grupy analizowanych periodyków Autorzy włączyli: „American Journal of Political Science”, „American Political Science Review”, „Comparative Political Studies”, „Comparative Politics”, ,International Organization”, „International Studies Quarterly”, „, Journal of Conflict Resolution”, „,Journal of Politics”, „Political Science Quarterly”, „World Politics”; A. Bennett, A. Barth, K.R. Rutherford, Do we preach what we practice? A survey of methods in political science journals and curricula, „PS: Political Science \& Politics" 2003, Vol. 36, No. 3, s. 374.

2 Ibidem, s. 373.

3 Zob. np. A. Chodubski, O kształtowaniu się metody politologicznej, [w:] Podejścia badawcze i metodologie w nauce o polityce, red. B. Krauz-Mozer, P. Ścigaj, Kraków 2013, s. 443-444; A. Chodubski, Wstęp do badań politologicznych, Gdańsk 2004, s. 116-117; W. Jakubowski, P. Załęski, Ł. Zamęcki, Nauki o polityce. Zarys koncepcji dyscypliny, Biškek-Pułtusk 2013, s. 34-35.

4 Zob. np. Z. Blok, Teoria polityki. Studia, Poznań 1998; M. Karwat, Syndromatyczny charakter 
się raczej ku drugiemu ze stanowisk, to końca tej debaty ogłosić nie można. Wynika to wszakże z innych problemów, odnoszących się zarówno do refleksji politologicznej $j^{5}$, jak i metodologii nauki w ogóle ${ }^{6}$. Nie ma to jednak większego znaczenia dla dalszych rozważań.

Przyjmuję w tym miejscu, że metoda naukowa, a także zastosowanie poszczególnych metod i technik badawczych ${ }^{7}$ zwiększają prawdopodobieństwo sukcesu poznawczego (choć go nie zapewniają!), a więc opisania, wyjaśnienia lub

przedmiotu nauki i polityce, [w:] Demokratyczna Polska w globalizującym się świecie, red. K.A. Wojtaszczyk, A. Mirska, Warszawa 2009; T. Klementewicz, Rozumienie polityki. Zarys metodologii nauki o polityce, Warszawa 2010, s. 57-64; B. Krauz-Mozer, Teorie polityki: założenia metodologiczne, Warszawa 2005; F. Pierzchalski, Polityka jako rozmyty przedmiot badań, [w:] Metafory polityki 4, red. B. Kaczmarek, Warszawa 2013; R. Rosicki, W. Szewczak, O przedmiocie badań politologii. Czy możliwa jest ogólna teoria polityki?, „Studia Polityczne” 2012, nr 29.

5 Idzie tu o liczne kłopoty związane z właściwościami przedmiotu badania politologii oraz założeniami ontologicznymi i epistemologicznymi, które skutkują wieloma podziałami wewnątrz dyscypliny; zob. np. G.A. Almond, A Discipline Divided: Schools and Sects in Political Science, Londyn 1990, s. 13-16; B. Grofman, Seven Durable Axes of Cleavage in Political Science, [w:] Contemporary Empirical Political Theory, red. K.R. Monroe, Berkeley-Los Angeles 1997, s. 74-79; R.A. Dahl, Complexity, change and contingency, [w:] Problems and Methods in the Study of Politics, red. I. Shapiro, R.M. Smith, T.E. Masoud, Cambridge 2004, s. 377-381; B. Krauz-Mozer, Wzorce „naukowości” politologii, „Studia Nauk Politycznych" 2004, vol. 1, nr 1, s. 25-38.

6 Trzeba pamiętać, że na polu metodologii nauki dalej toczą się spory, i to począwszy od poziomu najogólniejszego, a więc od pytania o kryteria i funkcje metody naukowej w ogóle aż po techniki badawcze. Szczególnie istotne okazały się dziewiętnastowieczne nadzieje na określenie metody naukowej będącej jednocześnie właściwym kryterium demarkacji nauki i nie-nauki. Larry Laudan słusznie powiada, że to oczekiwanie - zwłaszcza w obliczu niedających się dowieść i uzasadnić założeń na temat jedności nauki oraz licznych sporów co do tego, jak owa metoda miałaby zostać zdefiniowana - okazało się płonne. Jak się zdaje, nie należy jednak z naukowej wiedzy rezygnować, bo ma ona sukcesy większe aniżeli w przypadku innych rodzajów ludzkiej wiedzy - szczęściem naukowców było to, że w ostatnich kilku wiekach okazywali się bardziej racjonalni od magów czy teologów; L. Laudan, Zgon problemu demarkacji, [w:] Z badań nad prawda, nauką i poznaniem, red. Z. Muszyński, Lublin 1998, s. 67-69.

7 Mówiąc o „metodzie naukowej”, mam na myśli za Stefanem Nowakiem „pewien określony sposób postępowania zmierzającego świadomie do realizacji pewnego celu czy pewnej kategorii celów poznawanych w nauce”; S. Nowak, Metodologia badań społecznych, Warszawa 2007, s. 19.

Używając pojęcia metod badawczych (często w zapisie skróconym, jako „metoda” w określeniu „metody i techniki badawcze”), będę także posługiwał się definicją Nowaka, zgodnie z którą to „przede wszystkim typowe i powtarzalne sposoby zbierania, opracowywania, analizy i interpretacji danych empirycznych, służące do uzyskiwania maksymalnie (lub optymalnie [...]) uzasadnionych odpowiedzi na stawiane w nich pytania”; ibidem, s. 22. Pojęcie „technik badawczych” jest dla mnie pojęciem węższym od „metod badawczych” i odnosi się do zespołu szczegółowych czynności związanych z przeprowadzaniem badań; J. Sztumski, Wstęp do metod i technik badań społecznych, Katowice 2005, s. 82. 
zrozumienia (nawet ułomnego) jakiegoś zjawiska, bardziej aniżeli wykorzystanie jakichkolwiek metod dostępnych na gruncie innych form wiedzy ludzkiej. Dzieje się tak za sprawą przestrzegania pewnych wymogów stawianych badaniom naukowym, a w szczególności: systematyczności, precyzyjności i posługiwania się komunikatywnym językiem, sprawdzalności i kontrolowalności procedury badawczej oraz możliwości powtórzenia badań8. To one, a szczególnie ostatnia, dają możliwość ugruntowania teorii w świadectwach empirycznych - nie dając pewności, czynią ją jednak bardziej prawdopodobną.

Oczywiście w tym miejscu pojawia się naturalne pytanie, co z metodami nieempirycznymi, które w obszarze nauki występują i są szczególnie ważne dla politologii. Sądzę, że także one powinny spełniać powyższe wymogi, wyjąwszy warunek ugruntowania w świadectwach empirycznych. Powinny być systematyczne, komunikowalne i kontrolowalne w tym sensie, żeby można było odtworzyć wywód autora na podstawie tych samych danych/przesłanek. Nie zawężam więc, wbrew pozorom, pojęcia metod badawczych wyłącznie do badań empirycznych, przyjmując za Józefem M. Bocheńskim, że nauka jest pełna rozmaitych metod, w tym: fenomenologicznych, semiotycznych, aksjologicznych oraz redukcyjnych ${ }^{9}$. Nie ma potrzeby wszystkich w tym miejscu przywoływać, dość powiedzieć, że podział ten daje nam obraz złożoności metod badawczych.

Uważam, podobnie jak wielu badaczy, że podnoszenie świadomości metodologicznej oraz upowszechnianie wiedzy na temat założeń, celów oraz rezultatów stosowanych metod badawczych są potrzebne. Za ważne uznaję także to, by w tekstach naukowych obecna była deklaracja dotycząca wykorzystanych metod i technik badawczych. Ułatwia to bowiem sprawdzenie oraz ewentualne powtórzenie badań, a przez to przyczynia się do zwiększenia kontroli uzyskiwanych wyników. Nie jest to wszakże warunek niezbędny i konieczny. Warto wspomnieć, że wielu uznanych i cenionych badaczy nie tylko nie umieszcza informacji na

\footnotetext{
${ }^{8} \mathrm{Na}$ jeden lub większą liczbę tych wymogów, nie zawsze stosując takie właśnie kategorie, zwracają uwagę m.in. E. Agazzi, Dobro, zło i nauka. Etyczny wymiar działalności naukowo-technicznej, Warszawa 1997, s. 11-20; J. Buttolph Johnson, H.T. Reynolds, J.D. Mycoff, Metody badawcze w naukach politycznych, Warszawa 2010, s. 15-17 oraz 58-59; C. Frankfort-Nachmias, D. Nachmias, Metody badawcze w naukach społecznych, Poznań 2001, s. 28-32; C. Hempel, Filozofia nauk przyrodniczych, Warszawa 2001, passim; A.C. Isaak, Scope and methods of political science. An introduction to the methodology of political inquiry, Homewood 1975, s. 26-27; B. Krauz-Mozer, Metodologiczne problemy wyjaśniania w nauce o polityce, Kraków 1992, passim; B. Krauz-Mozer, W. Szostak, Teoria polityki. Podstawy metodologiczne politologii empirycznej, Kraków 1993, passim; R. Mayntz, K. Holm, P. Hübner, Wprowadzenie do metod socjologii empirycznej, Warszawa 1985, s. 11-30; S. Nowak, op.cit., s. 19-22.

9 J.M. Bocheński, Współczesne metody myślenia, Poznań 1992, passim.
} 
temat stosowanych metod, ale wręcz uznaje niekiedy pogłębioną koncentrację na procedurach za przesadną i bez większego znaczenia dla sukcesu badawczego ${ }^{10}$. Innymi słowy, sytuacja, w której brakuje informacji o zastosowanych metodach, jest dość częsta i nie musi w żadnym przypadku przekładać się na niższą wartość poznawczą wyników badań ani być oznaką metodologicznych błędów i uchybień. Informacja taka wydaje się wszakże przydatna $\mathrm{z}$ perspektywy kontroli procesu badawczego.

\section{CELE I HIPOTEZY BADAWCZE}

Celem tego artykułu jest próba odpowiedzi na tytułowe pytanie: czy uczymy o tym, w jaki sposób badamy? Spróbuję przedstawić zawartość wybranych sylabusów kursów metodologicznych prowadzonych w niektórych ośrodkach kształcenia politologicznego w Polsce oraz metody i techniki badawcze zastosowane przez Autorów artykułów opublikowanych w ośmiu politologicznych czasopismach naukowych w roku 2013.

Stawiam w tym miejscu ogólną hipotezę, że metody i techniki badawcze obecne w treści sylabusów są również najczęściej stosowanymi metodami i technikami w badaniach naukowych. Hipoteza ta wynika z założenia że politologia, podobnie jak inne dyscypliny nauk społecznych, zawiera pewien zbiór metod i technik, które są w niej wykorzystywane, i to bez względu na to, czy są to metody empiryczne czy nieempiryczne. Jak pamiętamy, niektórzy twierdzą, że może istnieć metoda (metody) unikatowa, inni kładą nacisk na wspólność z metodami innych nauk społecznych i humanistycznych. Ten spór nie ma tu jednak znaczenia. Ważne jest to, że jeśli taki zbiór charakterystycznych metod i technik istnieje, to powinien być nauczany. Trudno bowiem mówić o właściwej edukacji w zakresie dyscypliny bez przedstawienia jej metodologicznych podstaw. Krótko mówiąc, metodologiczna specyfika powinna ujawniać się zarówno na poziomie dydaktycznym, jak i badawczym i powinien być to obraz wewnętrznie spójny, a przynajmniej do pewnego stopnia zbieżny.

10 Jak powiada Marek Bankowicz, takie stanowisko odnaleźć można w pracach Samuela P. Huntingtona, Juana J. Linza czy Guillermo O’Donnella; M. Bankowicz, Metodologia politologii według Sartoriego, referat wygłoszony w dniu 3 października 2014 roku na seminarium „Odmiany nauki o polityce" w Krakowie [maszynopis niepublikowany], s. 7. 


\section{PROCEDURA BADAWCZA}

Przeprowadzone badania były dwuetapowe: w pierwszej części analizowano treści wybranych sylabusów przedmiotów kształcenia metodologicznego, w drugiej podjęto badania nad zawartością wybranych politologicznych periodyków naukowych. Co za tym idzie, uznano, że treści sylabusów są wskaźnikiem tego, co jest nauczane, zaś deklarowane metody i techniki - tego, co jest stosowane. Założenia te są problematyczne i kontrowersyjne, z czego zdaję sobie sprawę, jednak zostały one przyjęte w tym artykule.

W obydwu etapach stosowaną metodą badawczą była analiza treści ${ }^{11}$. Stworzone arkusze kodowe zawierały zarówno zmienne dwuwartościowe, dla których warianty zostały określone a priori, jak i zmienne wielowartościowe, których lista została ostatecznie zamknięta po wstępnej fazie kodowania ${ }^{12}$.

W przypadku sylabusów dobór próby miał charakter okolicznościowy i przebiegał w następujący sposób: na podstawie badań w ramach projektu Kim jesteś politologu?, realizowanych przez zespół pod kierownictwem Barbary Krauz-Mozer, określono listę 74 szkół wyższych, które w roku akademickim 2008/09 wykazywały studentów na kierunku politologia ${ }^{13}$. Następnie ustalono, czy sylabusy do przedmiotów metodologicznych są dostępne na stronach internetowych i czy uczelnie z listy prowadzą jeszcze kierunek studiów. W przypadku

11 Na temat analizy treści zob. np. B. Berelson, Content Analysis in Communication Research, Glencoe 1952; M. Lisowska-Magdziarz, Analiza tekstu w dyskursie medialnym: przewodnik dla studentów, Kraków 2006; S. Pamuła, Metoda analizy zawartości prasy i jej zastosowanie w wybranych periodykach, Częstochowa 1996; W. Pisarek, Analiza zawartości prasy, Kraków 1983; idem, Polskie słowa sztandarowe i ich publiczność, Kraków 2002.

12 W przypadku kodowania sylabusów zmienne dwuwartościowe odnosiły się do obecności lub nieobecności treści na temat: (a) założeń i podstaw badań naukowych, (b) elementów i przebiegu procesu badawczego, (c) podziału oraz sposobów postępowania ze źródłami, (d) sposobów analizy i interpretacji danych, (e) przygotowania raportów lub innych prac pisemnych, (f) inne. Zmienna „metody i techniki badawcze” przyjmowała wiele wartości w zależności od tego, jaka metoda lub technika była w sylabusie wymieniona. Podobnie było ze zmienną „literatura”. Wartości zmiennych zostały określone po wstępnym kodowaniu na podstawie zawartości sylabusów.

Gdy idzie o kodowanie treści artykułów naukowych, procedura była zbliżona. Do zmiennych dwuwartościowych zaliczono takie jak: (a) treść odnosząca się do problematyki polskiej, (b) wykorzystanie danych liczbowych, (c) wykorzystanie zaawansowanych technik statystycznych. Do zmiennych wielowartościowych zaliczono: (a) pole badawcze artykułu, rozumiane jako obszar tematyczny nauki o polityce, w który artykuł się wpisuje, (b) metody i techniki badawcze. Także i w tym przypadku wartości zmiennych wielowartościowych zostały określone po wstępnym kodowaniu.

${ }^{13}$ Więcej na ten temat zob. B. Krauz-Mozer, P. Borowiec, P. Ścigaj, Kim jesteś politologu? Historia i stan dyscypliny w Polsce, t. 1, Kraków 2011, s. 172. 
braku sylabusa na stronie internetowej wysyłano zapytanie drogą elektroniczną o możliwość jego udostępnienia. Ostatecznie próba liczyła 24 sylabusy, w tym 15 dla przedmiotów metodologicznych prowadzonych na studiach II stopnia (w tym $13 \mathrm{w}$ uczelniach publicznych) oraz 9 prowadzonych na studiach I stopnia (wszystkie w uczelniach publicznych) ${ }^{14}$.

Inaczej nieco przedstawia się dobór próby w analizie artykułów. Zastosowałem w tym przypadku dobór celowy, wybierając osiem periodyków zaliczanych powszechnie do czasopism politologicznych. W analizie wzięto pod uwage wyłącznie rok 2013, co jest wyborem arbitralnym. Nie analizowano żadnych autorskich publikacji książkowych ani rozdziałów w pracach zbiorowych. Łączna liczba analizowanych artykułów wynosiła 280 . Strukturę próby artykułów prezentuje tabela 1.

Tabela 1. Struktura próby analizowanych artykułów z periodyków politologicznych w roku 2013

\begin{tabular}{|c|c|c|c|c|c|c|}
\hline & \multirow{2}{*}{ Skrót } & \multirow{2}{*}{$\begin{array}{l}\text { Punkty } \\
\text { MNiSW }\end{array}$} & \multirow{2}{*}{$\begin{array}{c}\mathrm{N} \\
\text { numerów }\end{array}$} & \multirow{2}{*}{$\begin{array}{c}\mathrm{N} \\
\text { artykułów }\end{array}$} & \multicolumn{2}{|c|}{$\begin{array}{l}\text { W tym w języku } \\
\text { angielskim }\end{array}$} \\
\hline & & & & & $\mathrm{N}$ & $\%$ \\
\hline $\begin{array}{c}\text { Athenaeum. Polskie Studia } \\
\text { Politologiczne }\end{array}$ & A.PSP & 7 & 4 & 46 & 11 & $23,91 \%$ \\
\hline Polish Political Science Review & PPSR & 0 & 1 & 7 & 7 & $100,00 \%$ \\
\hline Politeja & $\mathrm{P}$ & 8 & 4 & 101 & 22 & $21,78 \%$ \\
\hline Przegląd Politologiczny & PP & 6 & 4 & 59 & 15 & $25,42 \%$ \\
\hline Studia Humanistyczno-Społeczne & $\mathrm{SH}-\mathrm{S}$ & 3 & 1 & 11 & 0 & $0,00 \%$ \\
\hline Studia Politologiczne & SPg & 8 & 4 & 25 & 2 & $8,00 \%$ \\
\hline Studia Polityczne & SP & 7 & 2 & 24 & 1 & $4,17 \%$ \\
\hline $\begin{array}{l}\text { Teka Komisji Politologii i Stosun- } \\
\text { ków Międzynarodowych O.L. PAN }\end{array}$ & Teka & 4 & 1 & 7 & 3 & $42,86 \%$ \\
\hline \multicolumn{3}{|l|}{ Ogółem } & 21 & 280 & 61 & $21,79 \%$ \\
\hline
\end{tabular}

Z analizy wyłączono teksty w językach innych aniżeli polski i angielski oraz recenzje.

Źródło: opracowanie własne.

$14 \mathrm{Na}$ marginesie można dodać, że opisywana procedura ujawniła dramatyczny spadek liczby uczelni prowadzących kierunek studiów „politologia”. Blisko 30 uczelni wyższych, w zasadzie wyłącznie niepublicznych, nie prowadziło w roku akademickim 2013/14 ani kierunku studiów, ani rekrutacji na politologię. 
Nie można w tym miejscu nie wspomnieć o ograniczeniach procedur doboru próby - wyraźnie bowiem zawężają one zasięg i siłę wysuwanych wniosków. Zastosowanie doboru okolicznościowego oraz celowego utrudnia, a nawet uniemożliwia uogólnianie wyników poza zebrany materiał badawczy. Jest to szeroko dyskutowany i powszechnie wskazywany problem ${ }^{15}$. Wypada więc podkreślić, że prezentowane w tym artykule wyniki odnoszą się tylko i wyłącznie do przeanalizowanych sylabusów oraz artykułów. Nie wolno na ich podstawie twierdzić nic na temat kształcenia metodologicznego oraz dyskursu politologicznego w ogóle. Zawsze więc, gdy będę formułował zdania ogólne, należy pamiętać, że ich zasięg wyznaczają ograniczenia doboru próby.

Czy to oznacza, że prezentowane w tym artykule analizy i wnioski są bezwartościowe? Mam głębokie przekonanie, że tak nie jest. Nawet biorąc pod uwagę zawężony obszar analizy oraz ograniczony charakter potencjalnych wniosków, mogą one być ważnym źródłem informacji na temat metodologicznej charakterystyki nauki o polityce. Mogą stać się jednym z elementów skłaniających do refleksji nad kształceniem w zakresie metodologii oraz wykorzystywaniem określonych metod i technik w badaniach politologicznych. Jest to więc raport niekompletny, poniekąd wybrakowany, punktowo pokazujący pewne zagadnienia i problemy, co nie oznacza, że jest całkowicie pozbawiony wartości poznawczej. Mam nadzieję, że przedstawione w tym miejscu rozważania przyczynią się choć w małym stopniu do powiększenia naszej świadomości na temat metodologicznej kondycji nauki o polityce.

\section{O CZYM UCZYMY?}

Wypada rozpocząć od przypomnienia, że zgodnie rozporządzeniem MNiSW z 2007 roku wprowadzono w Polsce standardy kształcenia dla poszczególnych kierunków, w tym dla politologii, określając podstawowe treści dla przedmiotów z grupy przedmiotów kierunkowych oraz podstawowych ${ }^{16}$. Kurs metodologia

${ }^{15}$ Na ten temat zob. np. G. Babiński, Metodologia a rzeczywistość społeczna. Dylematy badań etnicznych, Kraków 2004, s. 176; J. Buttolph Johnson, H.T. Reynolds, J.D. Mycoff, op.cit., s. 244-245; M. Szreder, Metody i techniki sondażowych badań opinii, Warszawa 2004, s. 48-53.

16 Rozporządzenie Ministra Nauki i Szkolnictwa Wyższego z dnia 1 lipca 2007 roku w sprawie standardów kształcenia dla poszczególnych kierunków oraz poziomów kształcenia, a także trybu tworzenia $i$ warunków, jakie musi spełniać uczelnia, by prowadzić studia międzykierunkowe oraz makrokierunki, „Dziennik Ustaw” 2007, nr 164, poz. 1166. 
badań politologicznych został zaliczony do grupy kierunków podstawowych na studiach II stopnia, zaś jego treści kształcenia obejmowały: „Treści kształcenia: Pojęcie, właściwości i funkcje nauki. Status metodologiczny politologii. Przedmiot badań politologicznych. Funkcje nauki o polityce. Teoria wiedzy źródłowej i pozaźródłowej. Źródła w badaniach politologicznych. Zasady i metody interpretacji źródeł. Modele badań politologicznych - humanistyczny, behawioralny, strukturalny, historyczny, integralny. Metody badawcze w politologii - systemowa, decyzyjna, neoinstytucjonalna, porównawcza, symulacyjna, statystyczna, wnioskowania z milczenia źródeł. Zasady formułowania i realizowania problemów badawczych. Efekty kształcenia - umiejętności i kompetencje: prowadzenia badań politologicznych; korzystania z modeli i metod badawczych; kształtowania i rozwijania własnego warsztatu badawczego"17.

Dwie kwestie wymagają podkreślenia. Po pierwsze, dla studiów I stopnia nie wskazano, ani w grupie przedmiotów podstawowych, ani w grupie przedmiotów kierunkowych, na konieczność kształcenia w zakresie metodologii, pozostawiając to do decyzji jednostek, które mogły wprowadzić takie kursy w ramach puli przedmiotów fakultatywnych. Po drugie, treści kształcenia dla przedmiotu metodologia badań politologicznych określono dość ogólnie, kładąc nacisk na założenia badań naukowych, status politologii jako nauki oraz przegląd podejść badawczych. Co prawda wskazano na ogólne metody badawcze w politologii, wymieniając metody: systemową, decyzyjną, neoinstytucjonalną, porównawczą, symulacyjną, statystyczną oraz wnioskowania z milczenia źródeł, jednak nie doprecyzowano, jakie metody i techniki szczegółowe mogą w nich występować. Nie powinno to wszakże dziwić. Takie treści są zgodne z zawartością popularnych podręczników metodologicznych w polskiej politologii oraz wydają się należycie oddawać stanowisko politologów w zakresie tożsamości metodologicznej ${ }^{18}$.

Wspominam o tym dlatego, że treść owego rozporządzenia wydaje się widoczna w analizowanych sylabusach, i to zarówno dla kursów realizowanych na studiach I stopnia, jak i przedmiotów oferowanych na studiach II stopnia. Pozostają one pod większym wpływem regulacji z roku 2007, aniżeli późniejszych reform wprowadzających Krajowe Ramy Kwalifikacji dla Szkolnictwa Wyższego ${ }^{19}$. Te ostatnie, znoszące listę kursów podstawowych i kierunkowych,

17 Ibidem: załącznik nr 81. Standardy kształcenia dla kierunku studiów: politologia.

18 Zob. np. A. Chodubski, op.cit., s. 114-132; W. Jakubowski, P. Załęski, Ł. Zamęcki, op.cit., s. 190-203.

19 Rozporządzenie Ministra Nauki i Szkolnictwa Wyższego z dnia 2 listopada 2011 r. w sprawie Krajowych Ram Kwalifikacji dla Szkolnictwa Wyższego, „Dziennik Ustaw” 2011, nr 253, poz. 1520. 
przesuwając na jednostki kształcenia prawo ustalania programów kształcenia, nie wywarły większego wpływu na przedmioty metodologiczne. Pozostały one niemal bez wyjątku obowiązkowymi kursami na studiach II stopnia, pojawiając się w programach studiów I stopnia w zróżnicowanej formie - głównie jako kursy fakultatywne, choć kilka ośrodków wprowadziło je jako obligatoryjne, o czym trzeba wspomnieć.

Przechodząc do analizy wybranych sylabusów, należy wskazać, że zgodnie „Z duchem” standardów kształcenia z 2007 roku treści przedmiotów obecnych w programach studiów II stopnia w większym stopniu poświęcone są zagadnieniom ogólniejszym, takim jak „założenia badań naukowych” oraz „proces badawczy" (93,33\% oraz 73,33\% analizowanych sylabusów zawiera takie treści), podczas gdy na studiach I stopnia więcej mówi się o metodach i technikach badawczych $(88,89 \%$ sylabusów zawiera takie treści), choć często nie są one wymienione, zaś autorzy sylabusów pozostają przy ogólnym stwierdzeniu, że studenci otrzymują wiedzę z zakresu metod i technik badawczych ${ }^{20}$. Dzieje się tak w co drugim sylabusie na studiach I stopnia oraz w co piątym na studiach II stopnia (dane szczegółowe prezentuje tabela 2).

20 Trzeba tu przedstawić zasady kodowania treści sylabusów. Poszczególne kategorie, przedstawione w tabeli 2, składają się bowiem ze zróżnicowanych elementów występujących w sylabusach. I tak do kategorii (1) „założenia badań naukowych” zaliczono określenia odnoszące się do założeń leżących u podstaw nauki, podziału i typologii nauk, miejsca wiedzy naukowej pośród innych form ludzkiej wiedzy, podobieństw i różnic między politologią a innymi dyscyplinami nauk społecznych i humanistycznych, przeglądu paradygmatów i podejść badawczych, charakterystyki i funkcji teorii naukowej. Na kategorię (2) „proces badawczy” składają się takie treści, jak: etapy procesu badawczego, ograniczenia badań naukowych, formułowanie problemu badawczego, konceptualizacja, operacjonalizacja, hipotezy, wybór narzędzi badawczych, dobór próby, przeprowadzanie badań naukowych, zbieranie danych. Do kategorii (3) „metody i techniki badawcze” wliczono wszystkie określenia zawierające słowoformy zawierające określenia „metoda”, „technika” oraz nazwy własne poszczególnych metod i technik, np.: eksperyment, badania sondażowe, metoda instytucjonalna, metoda historyczna, kwestionariusz, obserwacja i wiele innych. Do kategorii (4) „źródła” zaliczono, m.in. takie określenia, jak: kwerenda, bibliografia, dokumenty źródłowe i ich podział, krytyka wewnętrzna i zewnętrzna źródeł, specyfika źródeł w politologii, zasady cytowania źródeł itp. Do kategorii (5) „,analiza, interpretacja danych" włączono takie określenia, jak: wybrane rodzaje analizy politologicznej, opracowywanie zgromadzonych materiałów, podstawy analiz statystycznych. (6) Kategoria „raporty, prace pisemne” składa się z określeń typu: struktura i przygotowanie raportu badawczego, przygotowanie pracy, prezentacja wyników badań, rodzaje i charakter prac naukowych, pisanie raportu końcowego itp. Kategoria „inne” zawiera wszystkie określenia niedające się przyporządkować do wcześniejszych kategorii. 
Tabela 2. Treści wybranych sylabusów przedmiotów metodologicznych

\begin{tabular}{|c|c|c|c|c|}
\hline \multirow{2}{*}{} & \multicolumn{2}{|c|}{ Studia I stopnia } & \multicolumn{2}{c|}{ Studia II stopnia } \\
\cline { 2 - 5 } & $\mathrm{N}$ & $\%$ & $\mathrm{~N}$ & $\%$ \\
\hline Założenia badań naukowych & 8 & 88,89 & 14 & 93,33 \\
\hline Proces badawczy & 6 & 66,67 & 11 & 73,33 \\
\hline Metody i techniki badawcze, & 8 & 88,89 & 10 & 66,67 \\
w tym wymienione & 4 & 44,44 & 7 & 46,67 \\
\hline Źródła & 3 & 33,33 & 3 & 20,00 \\
\hline Analiza, interpretacja danych & 3 & 33,33 & 6 & 40,00 \\
\hline Raporty, prace pisemne & 2 & 22,22 & 5 & 33,33 \\
\hline Inne & 1 & 11,11 & 6 & 40,00 \\
\hline
\end{tabular}

Źródło: opracowanie własne.

Uderzający jest fakt, że właściwie w co trzecim sylabusie realizowanym na studiach II stopnia nie znajdujemy informacji na temat nabywania przez studentów wiedzy i umiejętności na temat metod i technik badawczych! Pozostaje wierzyć, że to jedynie niedopatrzenie w konstrukcji sylabusa jest powodem takiej sytuacji i że jakieś metody i techniki są nauczane. Inaczej byłaby to sytuacja trudna do rozumienia, że na kursie metodologicznym nie kształci się w zakresie metod i technik badawczych.

Ponadto należy zauważyć, że w 40,00\% sylabusów mówi się o sposobach prowadzenia analiz oraz interpretacji danych, zaś w co trzecim o zasadach pisania raportów oraz prac przedstawiających wyniki badań. Jednocześnie w dwóch na pięć sylabusów znajdują się treści „inne”, takie jak historia dyscypliny, zwłaszcza w Polsce oraz rozwój ośrodków politologicznych.

W przypadku studiów I stopnia proporcje te ulegają odwróceniu. Częściej uczy się o metodach i technikach badawczych $(88,89 \%$, choć w wielu przypadkach nie wymienia się, o jakie metody i techniki idzie) oraz źródłach w badaniach politologicznych. Pozostałe kategorie pojawiają się rzadziej aniżeli na studiach II stopnia.

Warto zwrócić uwagę, że taki układ treści w analizowanych sylabusach może budzić pewien niepokój, albowiem o ile na studiach I stopnia przedmioty są bardziej ukierunkowane na zdobywanie wiedzy i umiejętności z zakresu metod i technik badawczych, o tyle w mniejszym stopniu kładą one nacisk na podstawy prowadzenia badań naukowych. Pojawia się w tym miejscu pytanie, czy można dobrze użytkować technikę bez wiedzy na temat skomplikowanego charakteru 
procesu badawczego w naukach społecznych wraz z jego ograniczeniami i problemami wynikającymi choćby z natury przedmiotu badania, uwarunkowań podmiotu badawczego, relacji podmiot-przedmiot itp. Odpowiedź leży jednak poza granicami tego artykułu.

Szczegółowa analiza wymienianych w sylabusach I stopnia metod i technik badawczych pokazuje, że najczęściej pojawiają się w nich: „kwestionariusz” oraz „obserwacja” (cztery wystąpienia w sylabusach, co daje 44,4\%), następnie „analiza treści”, „eksperyment” oraz „sondaż” (33,3\%), „badania niereaktywne”, „,badania terenowe”, ,,metoda instytucjonalna”, „metoda porównawcza”, ,pomiar”, "socjometria”, „metoda systemowa” oraz „wywiad” wymieniane są w $22,2 \%$ sylabusów, a więc występowały ledwie dwa razy, zaś „,ankieta”, „badania przekrojowe”, „metoda decyzyjna” oraz „quasi-eksperyment”, w 11,1\%. Ponieważ analizie poddano dziewięć sylabusów przedmiotów metodologicznych prowadzonych na studiach I stopnia, oznacza to, że obecność metod i technik z ostatniej grupy zawężona jest tylko do jednego wystąpienia w dziewięciu sylabusach.

Podobne wyniki przynosi analiza sylabusów ze studiów II stopnia. Najczęściej, bo cztery razy, wymieniono w nich „kwestionariusz” oraz „metody jakościowe”, co daje występowanie w 26,7\% sylabusów. Trzy razy wzmiankuje się o „ankiecie”, „obserwacji”, „metodzie instytucjonalnej”"21, „metodzie porównawczej” i „wywiadzie” (20,0\%). Dwa razy dydaktycy wspominają w swoich sylabusach, że uczą „,eksperymentu, „metody decyzyjnej”, „metody symulacyjnej”, „metod ilościowych”, ,socjometrii”, ,, sondażu” oraz „technik statystycznych” (13,3\%), zaś ledwie raz występowały takie metody i techniki, jak „analiza treści”, „,badania terenowe”, ,focus”, „metoda behawioralna”, , , metoda historyczna”, , metoda systemowa”, ,metoda wnioskowania z milczenia źródeł”, „, metody mieszane”, ,wtórna analiza danych" (6,7\%).

Interesującym źródłem informacji na temat kierunku kształcenia na przedmiotach metodologicznych jest także zalecana literatura przedmiotu. Może ona bowiem powiedzieć nam - choć nie wprost - o preferowanych w nauczaniu metodach i technikach badawczych. W analizowanych sylabusach wystąpiło łącznie 105 różnych pozycji bibliograficznych. Listę najczęściej pojawiających się przedstawia tabela 3 .

${ }^{21}$ Kategorie „metoda instytucjonalna” oraz „metoda neoinstytucjonalna” zostały potraktowane jako „metoda instytucjonalna”. 
Tabela 3. Literatura w sylabusach przedmiotów metodologicznych

\begin{tabular}{|c|c|c|c|c|c|}
\hline \multirow{2}{*}{ Lp. } & \multirow{2}{*}{ Pozycja bibliograficzna } & \multicolumn{2}{|c|}{ Studia I stopnia } & \multicolumn{2}{|c|}{ Studia II stopnia } \\
\hline & & $\mathrm{N}$ & $\%$ & $\mathrm{~N}$ & $\%$ \\
\hline 1. & $\begin{array}{l}\text { Chodubski A., Wstęp do badań politologicznych, Gdańsk } \\
2013 .\end{array}$ & 7 & 77,78 & 8 & 53,33 \\
\hline 2. & Nowak S., Metodologia badań społecznych, Warszawa 2007. & 3 & 33,33 & 8 & 53,33 \\
\hline 3. & $\begin{array}{c}\text { Teorie i metody w naukach politycznych, red. G. Stoker, } \\
\text { D. Marsh, Kraków } 2006 .\end{array}$ & 3 & 33,33 & 8 & 53,33 \\
\hline 4. & Babbie E., Badania społeczne w praktyce, Warszawa 2003. & 5 & 55,56 & 7 & 46,67 \\
\hline 5. & $\begin{array}{l}\text { Frankfort-Nachmias D., Nachmias Ch., Metody badawcze } \\
\qquad \text { w naukach społecznych, Poznań } 2001 .\end{array}$ & 3 & 33,33 & 6 & 40,00 \\
\hline 6. & $\begin{array}{c}\text { Krauz-Mozer B., Teorie polityki. Założenia metodologiczne, } \\
\text { Warszawa } 2005 .\end{array}$ & 3 & 33,33 & 6 & 40,00 \\
\hline 7. & $\begin{array}{c}\text { Shively W.P., Sztuka prowadzenia badań politologicznych, } \\
\text { Poznań } 2001 .\end{array}$ & 2 & 22,22 & 6 & 40,00 \\
\hline 8. & $\begin{array}{c}\text { Sztumski J., Wstęp do metod i technik badań społecznych, } \\
\text { Katowice } 2005 .\end{array}$ & 3 & 33,33 & 4 & 26,67 \\
\hline 9. & $\begin{array}{l}\text { Mayntz R., Holm K., Hubner P., Wprowadzenie do metod } \\
\text { socjologii empirycznej, Warszawa } 1985 .\end{array}$ & 2 & 22,22 & 3 & 20,00 \\
\hline 10. & $\begin{array}{c}\text { Dahl R., Stinebrickner B., Wspótczesna analiza polityczna, } \\
\text { Warszawa } 2007 .\end{array}$ & 1 & 11,11 & 3 & 20,00 \\
\hline 11. & $\begin{array}{c}\text { Przybylski H., Politologia: zarys problematyki, Katowice } \\
2004 .\end{array}$ & 1 & 11,11 & 3 & 20,00 \\
\hline 12. & $\begin{array}{c}\text { Klementewicz T., Rozumienie polityki, Zarys metodologii } \\
\text { nauki o polityce, Warszawa } 2011 .\end{array}$ & & 0,00 & 3 & 20,00 \\
\hline 13. & Popper K.R., Logika odkrycia naukowego, Warszawa 2002. & & 0,00 & 3 & 20,00 \\
\hline
\end{tabular}

Źródło: opracowanie własne.

Zwraca uwagę fakt, że w grupie najczęściej wykorzystywanych podręczników są zarówno te, które dotyczą założeń i ogólnej charakterystyki badań naukowych (np. poz. 2, 6, 12, $13 \mathrm{w}$ tabeli 3), zawierają przegląd politologicznych podejść badawczych (np. poz. $3 \mathrm{w}$ tabeli 3), jak i te, które przedstawiają szczegółowo określone metody i/lub techniki badawcze nauk społecznych (np. poz. 4, 5, 7, $8,9 \mathrm{w}$ tabeli 3) oraz są swego rodzaju kompendium wiedzy o dyscyplinie wraz z uszczegółowieniem właściwych dla niej metod badawczych (np. poz. 1 z tabeli 3). Pokazuje to dużą złożoność poszczególnych kursów oraz ich bogactwo treściowe. Można to uznać za zaletę kształcenia metodologicznego na kierunku 
politologia, albowiem absolwenci powinni być nie tylko świadomi istnienia określonych metod i/lub technik badawczych oraz możliwości ich stosowania, ale także dostrzegać problemy ontologiczne i epistemologiczne leżące u podstaw badań naukowych w ogóle. Niestety temu przekonaniu towarzyszyć może sceptycyzm co do możliwości przekazania wiedzy tak trudnej, obszernej i złożonej, zwłaszcza podczas trzydziestogodzinnego kursu, a tyle właśnie godzin najczęściej przeznacza się na kursy metodologiczne. Tych problemów nie da się jednak w odpowiedni sposób w tym miejscu rozwiązać.

\section{OBSZAR ZAINTERESOWAŃ BADAWCZYCH}

Analizę zawartości wybranych periodyków politologicznych rozpocznę od kwestii pobocznej dla pytania głównego, acz niewątpliwe ważnej i ciekawej, a mianowicie od przedstawienia częstości występowania określonych zagadnień politologicznych. Mówią one bowiem wiele na temat kluczowych tematów polskiej politologii, rysując jej obraz, wskazując problemy charakterystyczne i dla niej właściwe ${ }^{22}$.

Spośród 280 analizowanych artykułów największy odsetek (17,5\%) koncentrował się na zagadnieniach z zakresu „myśli politycznej”. Nie powinno to dziwić, zważywszy na fakt, że w roku 2013 ukazało się kilka numerów tematycznych periodyków, które koncentrowały się właśnie na tych zagadnieniach. Z tego właśnie względu problematyka ta występowała najczęściej w piśmie „Politeja” $(36,3 \%)$. We wszystkich innych czasopismach zagadnienie to pojawiało się rzadziej, poniżej średniej dla zbioru wszystkich artykułów.

Do często występujących kwestii należały także: „stosunki międzynarodowe” $(16,1 \%)$, „komunikowanie polityczne i media” (11,8\%) oraz „,integracja europejska” (11,1\%). Najwięcej publikacji pierwszego rodzaju występowało w „Studiach Politologicznych” (28\%) oraz w piśmie „Teka Komisji Politologii i Stosunków

22 Trzeba tu jeszcze poczynić krótką uwagę metodologiczną. Otóż kodowanie miało charakter otwarty, a więc poszczególne kategorie nie zostały narzucone z góry, lecz pojawiały się wraz z kodowaniem. Warto tu zastrzec kilka kwestii: po pierwsze, periodyki naukowe często grupują teksty pod kątem poruszanych problemów, nazywając je odpowiednio - większość kategorii kodowych stanowi ich odzwierciedlenie; po drugie, ze względu na fakt, że wyżej wymienione określenia różnią się od siebie, ujednolicono je (np. potraktowano łącznie myśl polityczną i filozofię polityki); po trzecie, w uzasadnionych zawartością artykułu przypadkach rezygnowano z przyporządkowania oryginalnego, kodując inaczej, aniżeli sugerowałaby grupa, do której został przypisany przez redakcję periodyku. 
Międzynarodowych O.L. PAN" (28,7\%). Problemy komunikologiczne poruszane były najczęściej w „Polish Political Science Review” (28,6\%) oraz „Politeji” (19,8\%). Integracja europejska była ważnym przedmiotem refleksji autorów pism "Teka Komisji Politologii i Stosunków Międzynarodowych O.L. PAN” (58,1\%) oraz „Athenaeum. Polskie Studia Politologiczne” (21,7\%). Rozkład występowania poszczególnych kategorii prezentuje wykres 1.

Wykres 1. Obszary zainteresowań badawczych w wybranych periodykach politologicznych

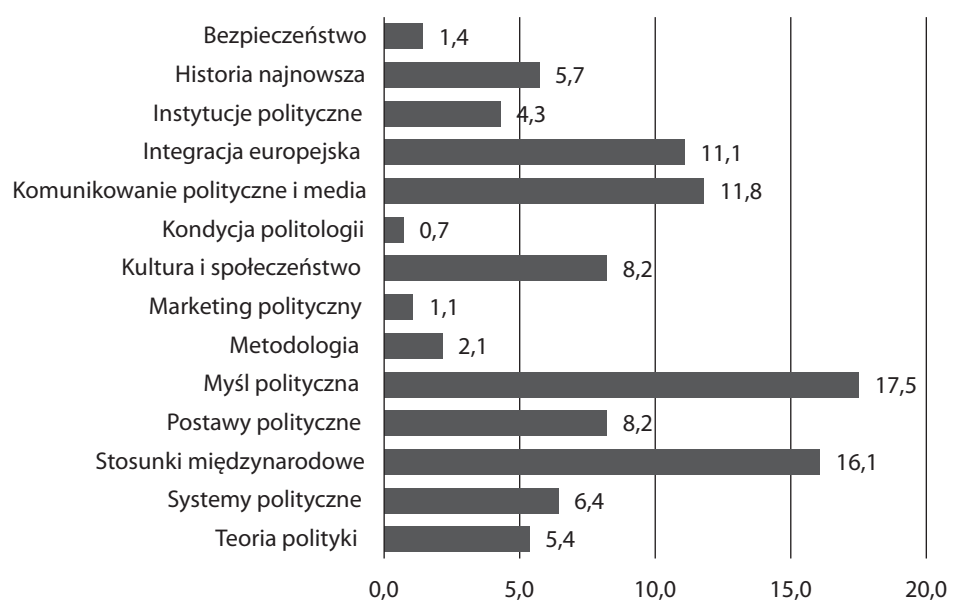

Źródło: opracowanie własne.

Warto wskazać, że w kodowaniu wyodrębniono zagadnienia „stosunki międzynarodowe” oraz „integracja europejska”. Można by słusznie argumentować, że jest to zabieg kłopotliwy i kontrowersyjny, albowiem drugie jest $\mathrm{z}$ konieczności częścią pierwszego. Trzeba więc pamiętać, że te dwie kategorie skumulowane stanowią łącznie 27,2\% ogółu publikowanych w roku 2013 w wybranych periodykach artykułów. Stanowi to bez wątpienia o istotności tego rodzaju zagadnień. 8,2\% publikowanych tekstów dotyczyło zagadnień „kultura i społeczeństwo” oraz "postawy polityczne”. W pierwszej grupie znalazło się wiele artykułów przedstawiających zwyczaje poszczególnych społeczeństw, ich historię czy wewnętrzne zróżnicowanie. Można uznać, że są to w zasadzie teksty kulturoznawcze publikowane w analizowanych periodykach. Gdy idzie o kategorię „postawy polityczne”, to dominowały wśród nich analizy zachowań wyborczych oraz norm i wartości politycznych właściwych dla poszczególnych społeczeństw. 
Analiza wyników $\mathrm{z}$ wykresu 1 prowadzić może do pewnego rodzaju zdziwienia związanego $\mathrm{z}$ relatywnie niewielkimi odsetkami artykułów poświęconych zagadnieniom „instytucji politycznych” oraz „systemów politycznych”. Co prawda te kategorie, skumulowane, stanowią 10,7\% ogółu tekstów z wybranych periodyków, jednak nie jest to wcale wartość znacząca, a przynajmniej można by oczekiwać wyższej. Takie przekonanie wypływa z badań zespołu pracującego pod kierownictwem Barbary Krauz-Mozer, opublikowanych w dwóch tomach pracy Kim jesteś, politologu? Wyniki badań sondażowych przeprowadzonych wśród wykładowców na kierunku politologia jednoznacznie pozwalały uznać, że do najważniejszych obszarów badawczych należą „stosunki międzynarodowe” oraz „Zagadnienia prawne, ustrojowe i instytucjonalne” (oba obszary wskazało 38,7\% respondentów $)^{23}$. I choć, co należy mocno podkreślić, wyniki te są kompletnie nieporównywalne i nie wolno $\mathrm{z}$ ich zestawienia wyciągać żadnych wiążących wniosków, to można powiedzieć, że dość niski odsetek artykułów poświęconych zagadnieniom instytucjonalnym oraz systemowym może zaskakiwać. Z pewnością nie dziwi natomiast popularność problematyki stosunków międzynarodowych oraz integracji europejskiej. Te wyniki wydają się zgodne z wcześniejszymi, nawet gdy weźmiemy pod uwagę wspomniane zastrzeżenia metodologiczne.

Kwestią, o której trzeba jeszcze powiedzieć przy okazji analizy obszarów badawczych, jest odsetek badań poświęconych Polsce. Z 280 analizowanych artykułów 88 wprost odnosiło się do zjawisk politycznych dziejących się w Polsce, co stanowi 31,4\% ogółu tekstów ${ }^{24}$. Najczęściej zagadnienia tego rodzaju pojawiały się w artykułach z zakresu „bezpieczeństwa” (75,0\%), ,instytucji politycznych” (75,0\%), „komunikowania politycznego i mediów” (72,7\%) oraz „postaw politycznych" $(69,6 \%)$.

Na pytanie, czy taki odsetek prac poświęconych Polsce to „dużo czy mało”, nie ma dobrej odpowiedzi. Nie wiemy tego, albowiem nie posiadamy badań porównawczych, które pozwoliłyby powiedzieć, że „taki a taki” odsetek jest typowy, zaś niższy lub wyższy świadczyć może o porzuceniu tego pola lub przeciwnie

${ }^{23}$ B. Krauz-Mozer, P. Borowiec, P. Ścigaj, Kim jesteś, politologu? Historia i stan dyscypliny w Polsce, t. II, Kraków 2012, s. 198-199.

24 Do grupy artykułów poruszających „polską” problematykę zaliczono te, które w całości lub znaczącej części odnosiły się do zjawisk politycznych dziejących się w Polsce, a więc takie, w których przedstawiono polskie instytucje polityczne, rolę Polski w procesach integracji europejskiej, stosunkach międzynarodowych, analizowano polską politykę wewnętrzną i zewnętrzną, postawy polityczne Polaków, procesy komunikacyjne polskiej polityki itp. Do grupy nie zaliczono artykułów, w których problematyka polska nie była przedmiotem badania wprost. 
- o nadmiernej reprezentacji. Ponadto z uwagi na zmienność politologicznych zainteresowań takie działania są zupełnie niepotrzebne i wprowadzać mogą mylne przekonanie o istnieniu jakiegoś względnie stałego przedmiotu badań. Pamiętając o tym, trudno jest ocenić odsetek tekstów poświęconych Polsce. Można jedynie wskazać, że bardzo niewiele artykułów, ledwie kilka, publikowanych w roku 2013 w wybranych periodykach było poświęconych analizie bieżących zjawisk politycznych w Polsce. Nie wolno na tej podstawie powiedzieć, że politolodzy „porzucili” analizy polskiej polityki, choć w świetle zebranych danych nie jest to twierdzenie nieprawdopodobne.

\section{METODY I TECHNIKI BADAWCZE}

Warto rozpocząć od uwagi, że 34 artykuły zawierają wyraźną deklarację co do zastosowanych metod i/lub technik badawczych, co stanowi 12,1\% ogółu analizowanych tekstów. Podobnie jak wcześniej, tak i tu trudno powiedzieć, czy to dużo czy mało, jednak z perspektywy czynienia zadość wymogom intersubiektywnej komunikowalności i kontrolowalności to raczej niewiele. Można powiedzieć ostro, że domyślanie się, jaką drogą autor czy autorka podążali, by ogłosić takie, a nie inne wnioski, nie sprzyja zrozumiałości i powtarzalności badań. Nie oznacza to co trzeba mocno i wyraźnie podkreślić - że takie badania są bezwartościowe lub błędne. Niczego takiego twierdzić nie wolno! Można natomiast przyznać, że tak jak bez przepisu trudno jest ugotować posiłek określnego rodzaju, tak bez opisu procedury badawczej trudno jest sprawdzić poprawność wniosków.

Metody i techniki badawcze są określone najczęściej w artykułach poświęconych „komunikowaniu politycznym i mediom” (36,36\%), „marketingowi politycznemu” (33,33\%) i „postawom politycznemu” (30,43\%). Niemal nigdy nie pojawiają się w pracach poświęconych „myśli politycznej” $(2,04 \%)$ oraz „historii najnowszej" $(0,00 \%)$. Takie wartości również nie powinny budzić zdziwienia. W badaniach z pierwszych trzech obszarów częściej wykorzystuje się metody wykorzystujące źródła wywołane i powstałe na gruncie innych nauk społecznych - socjologii, psychologii czy nauki o komunikowaniu. W takich przypadkach rzeczywiście liczba deklaracji na temat wykorzystanych metod wzrasta. Są one natomiast niemal nieobecne w pracach, których autorzy sięgają po tradycyjne dla politologii metody zakorzenione w bliskich relacjach $\mathrm{z}$ historią, prawem i filozofią.

Szczegółowa analiza deklaracji dotyczących wykorzystywanych w badaniach metod i technik pokazuje, że najczęściej w grupie badanych artykułów korzy- 
stano $\mathrm{z}$ analizy treści oraz $\mathrm{z}$ metody porównawczej (po 37,5\%), nieco rzadziej z różnego rodzaju analiz statystycznych oraz metody sondażowej (odpowiednio 29,2\% oraz 25,0\%). Szczegółowe dane prezentuje tabela 4.

Zwraca uwagę fakt, że lista wykorzystanych metod i technik jest wewnętrznie niespójna i złożona. Obok metod (np. porównawcza, historyczna, sondażowa) występują określenia dla technik zbierania danych (np. wywiad semiustrukturyzowany), analizy danych przy wykorzystaniu technik statystycznych oraz metoda doboru próby (metoda kuli śnieżnej). Nie jest to wszakże nic dziwnego, zważywszy na fakt, że nie ma skończonej i akceptowalnej dla ogółu badaczy listy metod i technik, zaś ich użycie jest pokłosiem problem badawczego.

Tabela 4. Określone w artykułach metody i/lub techniki badawcze

\begin{tabular}{|c|c|c|}
\hline Metoda i/lub technika badawcza & N & $\%$ \\
\hline Analiza treści & 9 & 37,5 \\
\hline Metoda porównawcza & 9 & 37,5 \\
\hline Analiza statystyczna ${ }^{*}$ & 7 & 29,2 \\
\hline Metoda sondażowa & 6 & 25,0 \\
\hline Metoda historyczna & 4 & 16,7 \\
\hline Metoda instytucjonalno-prawna & 4 & 16,7 \\
\hline Wywiady semiustrukturyzowane & 3 & 12,5 \\
\hline Triangulacja - metody jakościowe i ilościowe & 1 & 4,2 \\
\hline Wywiad ankietowy & 1 & 4,2 \\
\hline Metodologia teorii ugruntowanej & 1 & 4,2 \\
\hline Obserwacja uczestnicząca & 1 & 4,2 \\
\hline Metoda kuli śnieżnej & 1 & 4,2 \\
\hline Analiza decyzyjna & 1 & 4,2 \\
\hline
\end{tabular}

Określenia umieszczone w tabeli pochodzą z analizowanych artykułów za wyjątkiem oznaczonego *.

Odpowiedzi nie sumują się do 100\%, albowiem w niektórych artykułach deklarowano użycie więcej niż jednej metody lub techniki.

*W artykułach podawano różne techniki służące analizie statystycznej, które zostały włączone do jednej grupy.

Źródło: opracowanie własne. 
Sporo problemów nastręczała analiza artykułów, w których nie określono stosowanych metod i technik badawczych. Podkreślmy raz jeszcze, że nie oznacza to, iż nie były one używane w ogóle lub że były wykorzystywane błędnie. Brak określeń dotyczących metodologii jest z pewnością wyborem badacza, który nie musi mieć (i często nie ma) wpływu na jakość prowadzonych badań, w tym trafność doboru metody i technik oraz poprawność wniosków. Bez względu na to kłopoty w przeprowadzonych analizach związane były z koniecznością kodowania materiału surowego przy braku sprecyzowanych kategorii. Użyto w związku z tym dostępnych w popularnych podręcznikach politologicznych typologii metod i technik wraz z ich definicjami i według nich zakodowano materiał surowy ${ }^{25}$.

Najczęściej stosowanymi metodami w artykułach, w których nie określono metody i technik badawczych, były „analiza i krytyki piśmiennictwa” (83,3\%), a także „metoda historyczna” (44,3\%), „metoda instytucjonalno-prawna” (18,7\%), „wtórna analiza danych” (13,8\%), „analiza treści” (9,3\%), „metoda systemowa” $(5,3 \%)$ oraz „metoda porównawcza” (1,6\%). Pojawiły się także, choć nie zostały określone, przypadki wykorzystania metod właściwych dla teorii gier $(0,4 \%)$ oraz metody sondażowej (0,4\%). Oczywiście należy pamiętać o problemach, jakie pociąga za sobą kodowanie, zwłaszcza możliwych błędach po stronie kodera, jednak nawet jeśli były one obecne, to nie na tyle, aby zmienić zasadniczy wniosek, a mianowicie, że w dużej części artykułów publikowanych w roku 2013 w wybranych periodykach politologicznych o nieokreślonych metodach i technikach wykorzystywano te z nich, które są charakterystyczne dla tradycyjnej politologii zorientowanej historycznie, prawniczo i filozoficznie, oraz że są to także te metody, które część badaczy wspominanych wcześniej zalicza do grupy metod politologicznych.

\section{WNIOSKI}

Wnioski płynące z powyższych rozważań są następujące. Przedmioty metodologiczne na studiach I stopnia nie są obecne w każdym programie kształcenia, a jeśli są oferowane, to relatywnie większy nacisk jest w nich kładziony na metody i techniki badawcze, źródła oraz analizę i interpretację aniżeli na założenia

25 Zob. np. J. Apanowicz, Metodologia ogólna, Gdynia 2002, s. 72-73; A. Chodubski, op.cit., s. 114-132; W. Jakubowski, P. Załęski, Ł. Zamęcki, op.cit., s. 190-203; J. Pieter, Z zagadnień pracy naukowej, Wrocław 1974; idem, Zarys metodologii pracy naukowej, Warszawa 1975. 
badań oraz elementy składowe procesu badawczego. Dominują w nich metody nauk społecznych, korzystające głównie ze źródeł wywołanych (kwestionariusz, sondaż, eksperyment). Jednocześnie przedmioty metodologiczne na studiach II stopnia są powszechnie obecne w programie kształcenia, co jest najpewniej pozostałością obowiązujących wcześniej standardów kształcenia. Relatywnie większy nacisk jest w nich kładziony na założenia badań naukowych oraz elementy procesu badawczego aniżeli na szczegółowe metody i techniki, choć i te są obecne. W analizowanych sylabusach dominują metody i techniki nauk społecznych, korzystające głównie ze źródeł wywołanych, lecz pojawia się szersze omówienie metod i technik opierających się na źródłach zastanych. Ogólnie rzecz ujmując, w sylabusach przedmiotów realizowanych na studiach I stopnia oraz II stopnia relatywnie mało miejsca poświęca się metodom wskazywanym w wybranych podręcznikach jako właściwe politologii, a więc metodzie historycznej, decyzyjnej, systemowej oraz instytucjonalnej.

Wśród poruszanych problemów przez autorów publikowanych w wybranych periodykach politologicznych artykułach naukowych dominują treści związane z myślą polityczną, stosunkami międzynarodowymi (w tym integracją europejską), a także komunikowaniem politycznym i mediami oraz postawami politycznymi. W tym kontekście relatywnie mało miejsca poświęca się instytucjom politycznym i systemom politycznym.

W analizowanych artykułach naukowych rzadko umieszczano informacje na temat zastosowanych metod i technik. Dotyczyło to mniej więcej co dziesiątej pracy. W artykułach, w których określono metody, widoczne jest nachylenie w stronę metod opierających się najczęściej na źródłach wywołanych, zaś w artykułach, w których nie określono metod, widoczne jest nachylenie ku metodom opierającym się najczęściej na źródłach zastanych.

Warto też zwrócić uwagę, że w wielu pracach nie tylko nie wskazano wykorzystanych metod i technik, ale także nie określono problemu badawczego. Można powiedzieć, że artykuły, w których Autor(ka) jasno przedstawia problem badawczy, by na koniec analizy wrócić do niego i go rozwiązać, należą do niepokojącej mniejszości.

W kontekście naszego pytania tytułowego chyba najbardziej istotna jest obserwacja, że zasadniczo mało miejsca w sylabusach poświęca się metodom uznawanym za właściwe dla politologii w popularnych podręcznikach. Takie metody jak: historyczna, systemowa, decyzyjna, neoinstytucjonalna, porównawcza czy symulacyjna, są poruszane podczas bardzo niewielu kursów. Również najczęściej nie są one wskazywane jako wykorzystywane w badaniach politolo- 
gicznych (z wyjątkiem metody porównawczej), choć pojawiają się częściej, gdy metody i techniki nie są określone.

Mając to na względzie, należy uznać, że w świetle przedstawionych danych nie można uznać hipotezy, że metody i techniki badawcze obecne w treści sylabusów są również najczęściej stosowanymi metodami i technikami w badaniach naukowych, za potwierdzoną.

Na pytanie wiodące niniejszego artykułu - czy uczymy o tym, w jaki sposób badamy? - należy odpowiedzieć: raczej nie. Oczywiście odpowiedź ta jest ograniczona wyłącznie do materiału badawczego przedstawionego w tym miejscu i wszelkie próby przedstawiania wniosków sięgających poza ramy tych rozważań są wielce problematyczne. Nie osłabia to jednak, moim zdaniem, aż tak mocno podanej odpowiedzi. Jest bowiem prawdopodobne, że zbliżone wyniki uzyskamy, poszerzając bazę danych o większą liczbę artykułów, książek, sylabusów, a także przyjmując inne wskaźniki dla opisywanych zjawisk.

Jeśliby przyjąć ten tok rozumowania za poprawny, na koniec pozostaje próba odpowiedzi na pytanie: co dalej?, które - choć niewypowiedziane - od samego początku krąży nad tymi rozważaniami. Odpowiedź na nie wymaga jednak zgody co do założenia poczynionego wcześniej, a mianowicie, że dyscyplinę naukową powinna cechować swego rodzaju zgodność między edukacją metodologiczną i wykorzystywanymi w badaniach metodami i technikami.

Pytanie: co dalej? kieruje nas w stronę dwóch rodzajów odpowiedzi - dwóch rodzajów działań. Po pierwsze, na poziomie organizacji programów kształcenia oraz treści sylabusów należałoby podjąć kroki na rzecz: zwiększenia liczby godzin kształcenia w zakresie metodologii wraz z rozbiciem na problemy i zagadnienia metodologii apragmatycznej oraz wprowadzenia szeregu kursów odnoszących się do metodologii pragmatycznej, a więc przedstawiających charakterystykę i zastosowanie poszczególnych metod i technik. Trzeba rozważyć także wprowadzenie do sylabusów szczegółowego omówienia metod historycznych oraz prawniczych, bo są one istotnym elementem warsztatu badawczego politologa, podczas gdy są praktycznie nienauczane podczas kursów metodologicznych.

Po drugie, warto zabiegać o to, aby autorzy podawali metody i techniki, jakie stosują, nawet jeśli może wyglądać to niekiedy w sposób sztuczne czy wymuszone. W tym kontekście warto przemyśleć uzależnienie procesu wydawniczego w czasopismach naukowych od obecności wyraźnego określenia metod i technik. W taki sposób dbać będziemy o podnoszenie świadomości metodologicznej, ułatwiając także spełnienie wspomnianych wcześniej wymogów intersubiektywnej komunikowalności oraz kontrolowalności. 